\title{
ANALISIS CITRAAN DALAM ANTOLOGI PUISI RUMAH CINTA KARYA PENYAIR JAMBI
}

\author{
Nindi Riski Marsela ${ }^{1}$, Sumiharti ${ }^{2}$, Uli Wahyuni ${ }^{3}$ \\ Program Studi Pendidikan Bahasa dan Sastra Indonesia, \\ Fakultas Keguruan dan Ilmu Pendidikan, Universitas Batanghari, \\ Jambi
}

\author{
nindiriskimarsela@yahoo.com \\ harti.sumi@yahoo.com \\ adityagilangaditya@yahoo.co.id
}

\begin{abstract}
This research uses descriptive qualitative method. The data is taken from words or sentences and utterances which consist of imagery in the poetry anthology Rumah Cinta by penyair Jambi poet. Poetry is created based on observation that is recorded by senses to make images thought. The image of thought that can see, listen, feel, what it feels by the poet called imagery. From poetry, poet can reveal the bad and good things that they feel so that every poet can create more than two poetry. Moreover that poetry can be collected in a form of book. The book which consists of poetry collection that is created is called poetry anthology. Based on the result of this research, the most dominant imagery that is used by the poetry anthology Rumah Cinta by Jambi poet is imagery of sight. There are 30 utterances that are found and 3 utterances of imagery of movement.
\end{abstract}

Key Word: image, poetry anthology

\footnotetext{
${ }^{1}$ Mahasiswa Program Studi Pendidikan Bahasa dan Sastra Indonesia Fakultas Keguruan dan Ilmu Pendidikan, Universitas Batangharij Jambi

${ }^{2}$ Dosen Program Studi Pendidikan Bahasa dan Sastra Indonesia, Fakultas Keguruan dan Ilmu Pendidikan, Universitas Batanghari Jambi

${ }^{3}$ Dosen Program Studi Pendidikan Bahasa dan Sastra Indonesia Fakultas Keguruan dan Ilmu Pendidikan, Universitas Batanghari Jambi
} 


\section{PENDAHULUAN}

Karya satra dapat dikatakan sebagai seni yang memerlukan kreatifitas manusia sehingga dapat menciptakan sebuah karya yang indah. Dalam menciptakan sebuah karya sastra, penyair dapat dengan bebas berbicara tentang kehidupan sehari-hari berdasarkan intuisinya sehingga karya sastra mengandung makna yang dapat dijadikan sebagai media pendidikan bagi pembacanya.

Salah satu jenis karya sastra yang menggunakan bahasa indah dan padat akan makna adalah puisi. Puisi merupakan salah satu jenis karya sastra yang dapat dikaji dari berbagai aspek, diantaranya dari struktur dan unsur yang membangun puisi, serta dari tinjauan kesejarahannya. Puisi dapat dikaji dari struktur dan unsur yang membagun dikarenakan struktur puisi tersusun dari bermacam-macam unsur dan sarana kepuitisannya. Selanjutnya, puisi dapat dikaji dari tinjauan kesejarahannya mengingat bahwa sepanjang zaman puisi ditulis penyair dari waktu ke waktu mengalami perubahan. Puisi tidak hanya digunakan sebagai sarana penulisan, melainkan puisi juga digunakan untuk mengungkapkan keluh kesah yang dialami oleh penyairnya.

Puisi merupakan salah satu jenis karya satra yang digemari. Berdasarkan pengamatan peneliti perkembangan puisi di daerah Jambi sangat pesat, hingga bermunculan penyair-penyair Jambi seperti Rini Febriani Hauri, Buana K.S, Mhd. Ikhsan, dan Indarto Irwanto, Adi Suhara, Tiya Antoni, Titas Suanda, Jen Kelana, Aulia Murti, Iriani R. Tandy serta masih banyak lagi yang lainnya. Hasil karya dari penyair-penyair Jambi tersebut dikumpulkan dan dijadikan sebuah antologi puisi yang berjudul Rumah Cinta. Antologi puisi Rumah Cinta memuat 72 buah puisi yang diciptakan oleh 30 penyair Jambi.
Puisi yang terdapat dalam antologi puisi Rumah Cinta karya penyair Jambi memiliki batang tubuh yang tersusun dari struktur fisik dan struktur batin. Struktur tersebut sangat penting dalam membangun sebuah puisi, karena tanpa adanya struktur fisik dan struktur batin, puisi tidak dapat dinikmati ole para pembaca dengan keindahan yang dimilikinya. Struktur fisik dan struktur batin memiliki unsur-unsur pembangun, dan salah satu unsur pembangun puisi yang terkandung di dalam struktur fisik adalah citraan.

Permasalahan citraan pada hakikatnya tidak bisa terlepas dari permasalahan pemilihan kata (diksi). Dengan adanya diksi atau pilihan kata yang tepat tentu akan menimbulkan daya khayal pembaca terhadap suatu hal yang sedang dibacanya. Namun sebaliknya, penggunaan diksi yang tidak tepat tidak akan dapat membuat pembaca berimajinas seoah-olah merasakan apa yang dirasakan penyair, karena pada umumnya citraan dalam puisi digunakan penyair untuk memperkuat gambaran pemikiran pembaca, Citraan terdiri atas tujuh jenis yakni citraan penglihatan, citraan pendengaran, citraan perabaan, citraan penciuman, citraan gerak, citraan pencecapan, dan citraan pemikiran.

Fokus penelitian ini adalah analisis citraan penglihatan dan citraan gerak dalam antologi puisi Rumah Cinta karya penyair Jambi. Berdasarkan fokus penelitian yang telah diuraikan, maka pertanyaan dalam penelitian ini adalah bagaimanakah penggunaan citraan penglihatan dan citraan gerak dalam antologi puisi Rumah Cinta karya penyair Jambi?

Adapun tujuan penelitian secara umum digunakan untuk meningkatkan daya nalar dan untuk mencari jawaban permasalahan melalui penelitian. Berdasarkan fokus dan pertanyaan 
penelitian yang telah dipaparkan, maka tujuan penelitian ini adalah untuk mendeskripsikan citraan penglihatan dan citraan gerak dalam antologi puisi Rumah Cinta karya penyair Jambi.

Penelitian ini merupakan sebuah penelitian yang melibatkan karya sastra sebagai objeknya. Karya sastra merupakan suatu karya yang di dalamnya mengandung unsur keindahan. "Karya sastra adalah karya seni puitis" (Pradopo, 2017:13). Artinya, karya sastra mengandung unsur keindahan yang dapat membangkitkan perasaan, menarik perhatian, dan menimbulkan tanggapan yang jelas saat pembaca membacanya.

Karya sastra lahir karena perenungan yang dilakukan oleh penyair. "Karya sastra merupakan hasil renungan, khayalan, dan perasaan yang diwujudkan dalam kata-kata yang menimbulkan pesona" (Kosasih, 2008: 2). Artinya, karya sastra yang dihasilkan berasal dari hasil perenungan penyair terhadap keadaan di sekitarnya, kemudian dituangkan melalui kata-kata yang indah sehingga tidak menimbulkan rasa bosan saat membacanya.

Berbicara tentang karya sastra tidak lepas dari ragam atau jenisnya. Karya sastra terdiri dari beberapa jenis dan dibedakan menjadi beberapa versi. Semua karya sastra menarik dan nikmat untuk dibaca. Sugono (dalam Damayanti, 2013: 12-13) mengatakan beberapa jenis karya sastra meliputi puisi, prosa, dan drama dijelaskan sebagai berikut.

1. Puisi adalah jenis yang bentuknya dipilih dan ditata dengan cermat sehingga mampu pempertajam kesadaran orang akan suatu pengalaman dan membangkitkan tanggapan khusus lewat bunyi, irama, dan makna khusus.

2. Prosa adalah jenis sastra dengan bentuk paragraf yang bebas menggunakan kata-kata yang diinginkan pengarang. Prosa lebih dikenal dengan cerita kehidupan dan bahasa prosa sangat dekat dengan kehidupan sehari-hari.

3. Drama adalah jenis karya sastra yang bertujuan menggambarkan kehidupan lewat lakuan dan dialog (cakapan) para tokoh. Lazimnya dirancang untuk pementasan di panggung.

Rokhmansyah

menyatakan bahwa "Struktur batin puisi merupakan wacana teks puisi secara utuh yang mengandung arti atau makna yang hanya dapat dilihat atau dirasakan melalui penghayatan." Tanpa adanya sebuah penghayatan, unsur-unsur puisi yang membangun dari dalam tidak dapat dipahami secara benar. Menurut Waluyo (dalam Rokhmansyah, 2014: 26-30) struktur batin puisi memiliki empat unsur yaitu: tema (sense), perasaan (feeling), nada (tone), amanat dan (intention). Keempat unsure tersebut dijelaskan sebagai berikut.

a. Tema (Sense)

Tema adalah sesuatu yang diciptakan atau digambarkan penyair melalui puisinya yang mengandung suatu pokok persoalan yang hendak dikemukakan. Tema juga merupakan latar belakang terciptanya sebuah puisi, yang tidak dapat dipisahkan dengan pengarangnya. Dengan latar belakang pengetahuan yang sama, penafsir penafsir puisi akan memberikan tafsiran tema yang sama bagi sebuah puisi karena tafsir puisi bersifat lugas, obyektif, dan khusus.

b. Perasaan (Feeling)

Perasaan adalah sikap penyair terhadap pokok persoalan yang ditampilkannya. Perasaan penyair dalam puisinya dapat dikenal melalui penggunaan ungkapan-ungkapan yang digunakan dalam puisinya karena dalam menciptakan puisi suasana hati penyair 
juga ikut diekspresikan dan harus dapat dihayati oleh pembaca.

c. Nada (Tone)

Nada dalam puisi dapat diketahui dengan memahami apa yang tersurat, yaitu bahasa atau ungkapan-ungkapan yang dipakai dalam puisi. Nada berhubungan dengan suasana karena nada menimbulkan suasana tertentu pada pembacanya.

d. Amanat (Intention)

Penyair sebagai sastrawan dan anggota masyarakat baik secara sadar atau tidak merasa bertanggungjawab menjaga kelangsungan hidup sesuai dengan hati nuraninya. Oleh karena itu, puisi selalu ingin mengandung amanat (pesan). Meskipun penyair tidak secara khusus dan sengaja mencantumkan amanat dalam puisinya. Amanat tersirat dibalik tema dan juga dibalik kata yang diungkapkan penyair.

Pada uraian di atas telah dijelaskan mengenai struktur batin, dalam puisi terdapat unsur pembangun puisi yang berasal dari luar, yakni struktur fisik. Menurut Waluyo (dalam Kosasih 2008: 32-36) bahwa dalam puisi terdapat enam struktur fisik yaitu: diksi, pengimajian, kata konkret, bahasa figuratif (majas), rima atau ritma, dan tipografi. Keenam unsur tersebut dijelaskan sebagai berikut.

a. Diksi

Diksi merupakan kata-kata yang digunakan dalam puisi, hasil dari prtimbangan makna, susunan bait, maupun hubungan dengan kata-kata lain. Diksi yang dipilih bersifat konotatif.

b. Pengimajian

Pengimajinasian merupakan susunan kata yang dapat menimbulkan khayalan atau imajinasi yang dapat mempuat pembaca seolah-olah merasa, mendengar, melihat sesuatu yang diungkapkan penyair. c. Kata Konkret

Kata konkret merupakan sesuatu yang dapat membangkitkan imajinasi pembaca. Jika penyair mahir mengkonkretkan kata dengan baik maka pembaca dapat membayangkan secara jelas peristiwa atau keadaan yang dilukiskan oleh penyair.

d. Bahasa Figuratif (Majas)

Majas merupakan bahasa yang digunakan oleh penyair untuk mengungkapkan sesuatu dengan cara membandingkannya dengan benda atau kata lain. Majas digunakan untuk menyamarkan atau mengiaskan sesuatu dengan hal lain.

e. Rima atau Ritma

Rima merupakan pengulangan bunyi dalam puisi, dengan adanya rima maka puisi akan menjadi lebih indah. Makna yang ditimbulkannya akan lebih kuat.

f. Tipografi

Tipografi merupakan pembeda yang penting antara puisi, prosa, dan drama. Larik-larik puisi tidak berbentuk paragraf, melainkan bait.

Citraan merupakan salah satu unsur yang membangun struktur fisik sebuah puisi. Citraan dapat menimbulkan imajinasi pembaca. "Citraan merupakan kata atau susunan kata yang dapat menimbulkan khayalan atau imajinasi" (Kosasih, 2008: 33). Artinya, imajinasi yang dimiliki pembaca seolah-olah dapat merangsang pemikirannya sehingga pembaca dapat merasakan, mendengar, atau melihat sesuatu yang diungkapkan oleh penyair.

Citraan atau pengimajian merupakan susunan kata berdasarkan apa yang dilihat, didengar, maupun dirasakan penyair dengan menggunakan pancaindra. "Pengimajian adalah susunan kata-kata yang dapat mengungkapkan pengalaman sensoris di mana pembaca seolah-olah dapat melihat, mendengar, merasakan seperti apa yang dilihat, didengar, dan 
dirasakan penyair dalam puisinya secara imajinatif melalui pengalaman dan rasa" (Rokhmansyah, 2014: 18). Artinya, citraan yang digunakan penyair di dalam puisi berfungsi sebagai gambaran agar pembaca dapat mendapatkan gambaran secara jelas mengenai apa yang penyair lihat, dengar, serta rasakan.

Citraan memiliki beberapa jenis. dalam kajian ini penentuan kriteria atau jenis citraan berdasarkan atas sumber indera yang menghasilkannya. Menurut Pradopo (2017: 82) citraan terbagi menjadi tujuh yakni citraan penglihatan, citraan pendengaran, citraan perabaan, citraan penciuman, cintraan pencecapan, citraan pemikiran, dan citraan gerak. Berikut penjabaran dari ketujuh citraan tersebut.

\section{Citraan Penglihatan (Visual Imagery)}

Citraan penglihatan adalah jenis yang paling sering digunakan oleh penyair dibandingkan dengan citraan yang lain. Citraan penglihatan memberi rangsangan kepada indra penglihatan, hingga sering hal-hal yang tak terlihat seolah-olah terlihat.

2. Citraan Pendengaran (Auditory Imagery)

Citraan pendengaran juga sangat sering dipergunakan oleh penyair. Citraan pendengaran dihasilkan dengan menyebutkan atau menguraikan bunyi suara.

\section{Citraan Perabaan (Tectilel Imagery)}

Citraan perabaan ini melibatkan indra peraba (kulit). Citraan yang dapat dirasakan oleh indra peraba saat membacakan atau mendengarkan lariklarik puisi, sehingga penikmat dapat menemukan diksi yang dapat dirasakannya misalnya dingin, panas, lembut, kasar, dan sebagainya.

4. Citraan Penciuman

Citraan penciuman adalah citraan yang dapat dirasakan melalui indra penciuman atau yang berhubungan dengan gambaran yang dihasilakn oleh indra penciuman.

\section{Citraan Pencecapan}

Citraan pencecapan adalah citraan yang muncul dari puisi sehingga kita seakan-akan mencicipi suatu benda yang menimbulkan rasa pahit, manis, asam, dan lain-lain.

\section{Citraan Pemikiran}

Citraan pemikiran adalah citraan yang dihasilkan oleh citraan pemikiran seolaholah kita juga berfikir. Citraan pemikiran muncul dibenak pembaca karena merangsang pikiran untuk membayangkan bagaimana pesona tersebut memancar dari daun-daun. Padahal, pesona itu abstrak dan tidak dapat dilihat mata.

7. Citraan Gerak

Citraan ini menggambarkan sesuatu yang sesungguhnya tidak bergerak, tetapi seolah-olah bergerak, ataupun gambaran gerak pada umumnya. Citraan gerak ini membuat hidup dan gambaran menjadi dinamis.

Berdasarkan teori Pradopo, terdapat tujuh citraan dalam puisi tersebut, peneliti menjadikan teori Pradopo sebagai acuan dalam penelitian ini.

Puisi memiliki arti penting bagi peristiwa yang terjadi di dalam kehidupan sehari-hari. Penyair menulis puisi berdasarkan fenomena yang ada. Banyak penyair yang menulis puisi kemudian dijadiakan sebuah antologi puisi. "Antologi adalah kumpulan dari karyakarya sastra" (Pamungkas, 2005: 107). Istilah antologi tidak hanya digunakan pada puisi, melainkan digunakan dalam cerpen, syair dan lain-lain. Antologi merupakan kumpulan-kumpulan karya sastra yang ditulis oleh penyair.

Sajak atau puisi yang telah ditulis penyair dikumpulkan dan dipilah. "Antologi adalah kumpulan sajak-sajak pilihan dari seorang penyair atau beberapa beberapa penyair" (Suparno, 2008:106). 
Puisi yang ditulis oleh seorang penyair atau beberapa penyair dipilih karena setiap menulis sebuah puisi, penyair mengangkat tema yang berbeda-beda dalam sebuah antologi puisi.

Antologi puisi Rumah Cinta merupakan kumpulan puisi yang diterbitkan oleh Kantor Bahasa Provinsi Jambi, guna mengapresiasi karya-karya sastra berbentuk puisi yang ditulis oleh sastrawan Jambi. Selain itu, antologi puisi ini dijadikan salah satu refrensi untuk memahami cara pandang generasi moderen penyair di Jambi dalam memotret realitas melalui kerja penulisan puisi.

Puisi yang ditulis penyair merupakan hasil dari pergulatan antara situasi sosial yang ditangkap dan diinterpretasikan melalui puisi. Puisi-puisi tersebut dihasilkan oleh tiga puluh penyair yakni Rini Febriani Hauri, Adi Suhara, Mhd. Ikhsan, Aulia Murti, Indarto Irwanto, Iriani R. Tandy, C. H. Yurma, dan Utomo Soconingrat, Tiya Antoni, Titas Suwanda, Anggiri Penangsang, Asro Al Murthawy, Buana K. S, Neni R. Tyas, Jen Kelana, Bi Sugi Hartono, Miranti Julia, Dimas Arika Mihardja, Yupnical Suketi, Didik Mikroji, serta N. Eko Saputra, Eka Sutrisni, Arya Putra, Febrianiko Satria, Oki Akbar, Kawirian, M Deby Satria, Ahmad Yani AZ, Khairul Fajri, Okta Iswanto.

\section{METODE PENELITIAN}

Adapun penelitian ini bersifat deskriptif kualitatif. Menurut Nawawi (dalam Siswantoro 2010: 58) jenis deskriptif dapat diartikan sebagai prosedur pemecahan masalah yang diselidiki dengan menggambarkan atau melukiskan keadaan subjek dan objek penelitian (novel, drama, cerita pendek, puisi) pada saat sekarang berdasarkan fakta-fakta yang tampak atau sebagaiman adanya". Artinya seorang peneliti sastra dituntut mengungkapkan fakta yang tampak dengan cara mendeskripsikan.
Metode penelitian yang digunakan dalam penelitian ini adalah metode deskriptif kualitatif. Metode deskriptif kualitatif peneliti jadikan sebagai landasan penelitian karena dimaksudkan untuk menggambarkan, melukiskan citraan dalam antologi puisi Rumah Cinta karya penyair Jambi, kemudian datanya akan disajikan dalam bentuk kata-kata atau kalimat berdasarkan fakta-fakta yang ada.

Sumber data penelitian ini adalah antologi puisi Rumah Cinta karya penyair Jambi. Subjek penelitian berasal dari teksteks puisi yang berkaitan dengan kajian peneliti yaitu citraannya.

Pengumpulan data dalam penelitian ini menggunakan studi pustaka dan dokumentasi yang difokuskan untuk menganalisis citraan yang terdapat dalam antologi puisi Rumah Cinta karya penyair Jambi.

Teknik analisis data merupakan langkah yang strategis dalam penelitian. Langkah-langkah kegiatan menganalisis data dilakukan sebagai berikut:

1. Data yang telah dikelompokkan ke dalam teknik pengumpulan data kemudian ditabulasikan ke dalam tabel tabulasi data.

2. Menganalisis data sesuai dengan aspek citraan yang terdapat pada 32 puisi dalam antologi puisi Rumah Cinta karya penyair Jambi.

3. Mendeskripsikan data yang telah ditabulasikan secara jelas, agar data tersebut dapat dimengerti pembaca sesuai dengan data yang telah disiapkan.

4. Mengabsahkan data dengan tiga cara yakni: a) menkonsultasikan data dengan ahli.; b) mencocokan analisis data dengan teori yang dijadikan sebagai landasan penelitian ini; c) menyesuaikan analisis data ini dengan metode penelitian yang dipakai.

5. Merumuskan kesimpulan data yang sudah dianalisis dan dideskripsikan. 


\section{HASIL DAN PEMBAHASAN}

Hasil penelitian dan pembahasan objek penelitian ini disatukan dalam satu pemaparan. Secara berurut uraian berikut ini membahas dan menganalisis citraan puisi dalam antologi puisi Rumah Cinta karya penyair Jambi, yang meliputi citraan penglihatan dan citraan gerak yang terdapat dalam antologi puisi Rumah Cinta karya penyair Jambi.

Tabel 3 Tabulasi Pengumpulan Data

\begin{tabular}{cclc}
\hline No & Bentuk Citraan & \multicolumn{1}{c}{ Kutipan } & Hal \\
\hline 1 & Citraan Penglihatan & $\begin{array}{l}\text { Dalam sajak ini, aku mencarimu di antara lalu lalang } \\
\text { dan kerumunan orang-orang menuju pulang }\end{array}$ & 1 \\
\cline { 2 - 3 } & $\begin{array}{l}\text { Aku berjalan menelusuri pasar pagi itu Ditemani langit } \\
\text { buram, jalan yang lengang }\end{array}$ & 2 \\
\cline { 2 - 3 } & $\begin{array}{l}\text { Mawarku telah menjadi layu, Mahkotanya perlahan } \\
\text { gugur ke tanah }\end{array}$ & 42 \\
\cline { 2 - 3 } & $\begin{array}{l}\text { Aku yang telah tiba di antara lautan kendaraan dan } \\
\text { lautan pedagang Yang menjajakan dagangannya di } \\
\text { pinggir jalan gang-gang sempit }\end{array}$ & 2 \\
& \begin{tabular}{l} 
Asap-asap dapur penghuni pasar mengepul kental \\
\cline { 2 - 3 }
\end{tabular} & $\begin{array}{l}\text { Tentang masa kanak-kanak yang teriris, Tumbuh } \\
\text { dalam kepungan asap pabrik tua }\end{array}$ & \\
\hline 2 & Citraan Gerak & Musim-musim bergelayutan di awan & 6 \\
\cline { 2 - 3 } & $\begin{array}{l}\text { Setelah senja berangkat temaram dan kita akan } \\
\text { menuju pembaringan yang agung }\end{array}$ & 6 \\
\hline & $\begin{array}{l}\text { Sungai yang kini kian hilang, menyelami keadaan } \\
\text { muara teluk dan lubuk }\end{array}$ & 66 \\
\hline
\end{tabular}

Berdasarkan tabel tersebut, diketahui bahwa dari 32 puisi dalam antologi puisi Rumah Cinta karya penyair Jambi, terdapat 30 citraan penglihatan di dalam 19 puisi yaitu puisi Distikon Kau dan $A k u$ dua citraan penglihatan, puisi Pasar yang Tak Pernah Ditinggalkan dan Aku yang Telah Ditinggalkan dua citraan penglihatan, dan dua citraan penglihatan dalam puisi Secangkir Kopi Sebayang Kenangan, satu citraan penglihatan dalam puisi Muntalimun, satu citraan penglihatan dalam puisi Yang Memperjuangkan
Riwayat, satu citaan penglihatan dalam puisi Pada Malam yang Sejenak, satu citraan penglihatan dalam puisi Kepada Tepian, satu citraan penglihatan dalam puisi Ode Sebilah Mata Pisau, satu citaan penglihatan dalam puisi Kita yang Berkampung di Atas Air Mata, serta dua citraan penglihatan dalam puisi $D i$ Matamu yang Punai Itu, satu citraan penglihatan dalam puisi Langit di Ujung $M e i$, satu citraan penglihatan dalam puisi Aku Mencintaimu, satu citraan penglihatan dalam puisi Kumbang, dua citraan dalam

Analisis Citraan dalam Antologi Puisi Rumah Cinta Karya Penyair Jambi 
puisi Di Perkampungan Debu, satu citraan penglihatan dalam puisi Kukepalkan Tinju Asu, satu citraan penglihatan dalam puisi Sajak Kepergian, satu citraan penglihatan dalam puisi Sajak Kepergian 2, satu citraan penglihatan dalam pusi Air Mengalir ke Lembah-lembah, satu citraan penglihatan dalam puisi Batu yang Terbelah Tiga. Namun, peneliti hanya mencantumkan 5 puisi dengan citraan penglihatan dalam penelitian ini.

Citraan penglihatan adalah jenis citraan yang paling sering digunakan oleh penyair dibandingkan dengan citraan yang lain. "Citraan penglihatan adalah citraan yang timbul oleh indra penglihatan. Citraan ini menyebabkan pembaca seolaholah seperti melihat sendiri apa yang dikemukakan atau diceritakan oleh penyair" (Damayanti, 2013: 30). Jadi, citraan penglihatan ini memberikan rangsangan kepada indra mata. Citraan penglihatan dalam antologi puisi Rumah Cinta karya penyair Jambi terdapat pada kutipan, sebagai berikut:

(1.1) "Dalam sajak ini, aku mencarimu

di antara lalu lalang dan kerumunan orang-orang menuju pulang" (Distikon Kau dan Aku, Rini Febriani Hauri, hal 1).

Pada penggalan bait puisi tersebut, kata kerumunan orang-orang merupakan bagian dalam citraan penglihatan. Kata tersebut menggambarkan bahwa ada seseorang yang terlihat dikelilingi banyak orang disekitarnya. Berdasarkan hasil analisis peneliti, kajian tersebut sesuai dengan apa yang dikemukakan oleh Damayanti (2013: 30) bahwa citraan penglihatan menyebabkan pembaca seolah-olah melihat sendiri apa yang dikemukakan oleh penyair.

(1.2) "Mawarku telah menjadi layu, Mahkotanya perlahan gugur ke tanah" (Muntalimun, Febrianiko Satria, hal 42).
Dari penggalan bait puisi tersebut, citraan penglihatan yakni dari kata layu. Penyair menggambarkan bahwa ia melihat sesuatu yang tidak segar lagi dihadapannya. Berdasarkan hasil analisis peneliti, kajian tersebut sesuai dengan apa yang dikemukakan oleh Damayanti (2013: 30) bahwa citraan penglihatan menyebabkan pembaca seolah-olah melihat sendiri apa yang dikemukakan oleh penyair.

(1.3) "Aku berjalan menelusuri pasar pagi itu Ditemani langit buram, jalan yang lengang" (Pasar yang Tak Pernah Ditinggalkan dan Aku yang Telah Ditinggalkan, Rini Febriani Hauri, hal 2).

Pada penggalan bait puisi tersebut terdapat citraan penglihatan. Terlihat dalam kata jalan yang lengang yang dimaksudkan oleh penyair dalam bait puisi tersebut yakni ada seseorang yang terlihat sedang berada di jalan yang tidak ramai atau sepi. Kajian tersebut sesuai dengan apa yang dikemukakan oleh Damayanti (2013: 30) bahwa citraan penglihatan menyebabkan pembaca seolah-olah melihat sendiri apa yang dikemukakan oleh penyair.

(1.4) "Aku yang telah tiba di antara lautan kendaraan dan lautan pedagang Yang menjajakan dagangannya di pinggir jalan gang-gang sempit, Asap-asap dapur penghuni pasar mengepul kental" (Pasar yang Tak Pernah Ditinggalkan dan Aku yang Telah Ditinggalkan, Rini Febriani Hauri, hal 2).

Pada penggalan bait puisi tersebut terdapat citraan penglihata yakni dari kata lautan kendaraan dan lautan pedagang. Penyair menggambarkan bahwa ada seseorang yang terlihat dikelilingi kendaraan dan pedagang yang padat. Berdasarkan hasil analisis peneliti, kajian 
tersebut sesuai dengan apa yang dikemukakan oleh Damayanti (2013: 30) bahwa citraan penglihatan menyebabkan pembaca seolah-olah melihat sendiri apa yang dikemukakan oleh penyair.

(1.5) "Tentang masa kanak-kanak yang teriris, Tumbuh dalam kepungan asap pabrik tua" (Yang Memperjalankan Riwayat kepada mama, Mhd. Ikhsan, hal 7).

Pada bait tersebut asap merupakan citraan penglihatan.Penyair menggambarkan bahwa ia melihat seseorang yang dikelilingi asap tebal di sebuah pabrik tua. Berdasarkan hasil analisis peneliti, kajian tersebut sesuai dengan apa yang dikemukakan oleh Damayanti (2013: 30) bahwa citraan penglihatan menyebabkan pembaca seolah-olah melihat sendiri apa yang dikemukakan oleh penyair.

Pada citraan gerak peneliti menemukan 3 puisi, yakni dalam puisi Duh Punai Merindu terdapat satu citraan gerak, puisi Pada Malam yang Agung satu citraan gerak dan puisi Dendang Budak Tuan Tambang ditemukan satu citraan gerak. Sehingga, dari 32 puisi hanya tiga puisi yang mengandung citraan gerak.

Menurut Pradopo (2017: 88) "Citraan gerak ini menggambarkan sesuatu yang sesungguhnya tidak bergerak, tetapi seolah-olah bergerak, ataupun gambaran gerak pada umumnya. Citraan gerak ini membuat hidup dan gambaran menjadi dinamis". Jadi, citaan gerak ini dapat merasakan yang tidak bergerak seolaholah bergerak. Citraan gerak dalam antologi puisi Rumah Cinta karya penyair Jambi terdapat pada kutipan, sebagai berikut:

(5.1) "Musim-musim bergelayutan di awan" (duh, Punai Merindu, Adi Suhara, hal 60).

Dari penggalan bait puisi di atas, penyair menggambarkan citraan gerak dengan menggunakan kata bergelayutan. Bergelayutan adalah citraan gerak karena penyair menggambarkan kata-kata yang bergerak untuk musim-musim bergelayutan. Berdasarkan hasil analisis di atas dapat peneliti simpulkan bahwa kajian tersebut sesuai dengan apa yang dikemukakan oleh Pradopo (2017: 88) yakni citraan gerak ini menggambarkan sesuatu yang sesungguhnya tidak bergerak, tetapi seolah- Dari penggalan bait puisi tersebut, citraan

(5.2) "Setelah senja berangkat temaram dan kita akan menuju pembaringan yang agung" (Pada Malam yang Sejenak -untuk lizasari, Mhd. Ikhsan, hal 6).

Dari penggalan bait puisi di atas, penyair menggambarkan citraan gerak dengan berangkat. Berangkat berarti mulai berjalan. Penyair menggambarkan sesuatu yang tidak bergerak seolah-olah bergerak sehingga memancing penyair seolah-olah senja dapat berjalan. Berdasarkan hasil analisis di atas dapat peneliti simpulkan bahwa kajian tersebut sesuai dengan apa yang dikemukakan oleh Pradopo (2017: 88) yakni citraan gerak ini menggambarkan sesuatu yang sesungguhnya tidak bergerak, tetapi seolah-olah bergerak, ataupun gambaran gerak pada umumnya.

(5.3) "Sungai yang kini kian hilang, menyelami keadaan muara teluk dan lubuk" (Dendang Budak: Tuan Tambang, Titas Suwanda, hal 66).

Dari penggalan bait puisi di atas, penyair menggamabrkan citraan gerak dengan menyelami. Dengan kata-kata menyelami berarti penyair membuat pembaca seolah-olah ikut merasakannya. Berdasarkan hasil analisis di atas dapat peneliti simpulkan bahwa kajian tersebut sesuai dengan apa yang dikemukakan oleh Pradopo (2017: 88) yakni citraan gerak ini 
menggambarkan sesuatu yang sesungguhnya tidak bergerak, tetapi seolah-olah bergerak, ataupun gambaran gerak pada umumnya.

\section{SIMPULAN}

Dalam antologi puisi Rumah Cinta karya penyair Jambi, banyak menggunakan kata-kata atau kalimat serta ungkapan-ungkapan yang menggambarkan kepada pembaca bagaimana cara pandang penyair generasi modern di Jambi dalam melihat realitas yang terjadi melalui pergulatan antara situasi sosial yang ditangkap dan diinterpretasikan melalui puisi. Sehingga, berdasarkan hasil penelitian dan pembahasan, dapat disimpulkan bahwa terdapat citraan penglihatan dan citraan gerak dalam antologi puisi Rumah Cinta karya penyair Jambi. Akan tetapi, citraan yang dominan digunakan dalam antologi puisi Rumah Cinta karya penyair Jambi yakni citraan penglihatan. Citraan penglihatan selalu hadir dalam setiap puisi yang ada, hampir di setiap bait puisi ditemukan citraan penglihatan. Selain itu, meskipun tidak sebanyak citraan penglihatan, citraan gerak juga terdapat dalam antologi puisi Rumah Cinta karya penyair Jambi. Penyair menggunakan kata atau bahasa yang tepat, sehingga pembaca secara jelas dapat memahami citraan yang digunakn dalam antologi tersebut.

\section{DAFTAR PUSTAKA}

Damayanti, D. (2013). Buku Pintar Sastra Indonesia; Puisi, Sajak, Syair, Pantun, dan Majas. Yogyakarta: Araska.
Hauri, Rini Febriani, dkk. (2015). Rumah Cinta; Antologi Puisi Penyair Jambi. Jambi: Kantor Bahasa Provinsi Jambi.

Kosasih, E. (2008). Apresiasi Sastra Indonesia. Bandung: Nobel Edumedia.

(2012). Dasar-Dasar Keterampilan Bersastra. Yogyakarta: CV. Yarma Widya.

Pamungkas, Nandang $\mathrm{R}$ dan Ismail Kusmayadi. (2005). Aku Suka Bahasa Indonesia. Jakarta: Grafindo Media.

Pradopo, Rachmat Djoko. (2017). Pengkajian Puisi. Yogyakarta: Gajah Mada University Press.

Siswantoro. (2010). Metode Penelitian Sastra. Yogyakarta: Pustaka Pelajar.

Suparno. (2008). Bahasa dan Sastra Indonesia 2 SMP/MTS Kelas VIII. Jakarta: Bumi Aksara.

Wiyatmi. 2009. Pengantar Kajian Sastra. Yogyakarta: Pustaka Book Publisher.

Waluyo, Herman. J. (1991). Teori dan Apresiasi Puisi. Jakarta: Erlangga.

http://eprints.ums.ac.id/26701/13/11Naskah_Publikasi.pdf._(2013). "Aspek Citraan dalam Novel Pengantin Kecilku Karya Maria. A. Sardjono: Kajian Stilistika”. Online. (11 Desember 2017).

6. http://eprints.uny.ac.id/26785/1/skripsi .pdf. (2015). "Citraan Alam dalam Antologi Puisi Refrein di Sudut Dam Karya D. Zawawi Imron”. Online. (11 Desember 2017). 